\title{
ON THE RELATIONSHIP BETWEEN FIRM SIZE, RESOURCES, AGE AT ENTRY AND INTERNATIONALIZATION: THE CASE OF SLOVENIAN SMES
}

\author{
Mitja RUZZIER ${ }^{1}$, Maja KONECNIK RUZZIER ${ }^{2}$ \\ ${ }^{1}$ Department of Entrepreneurship, Faculty of Management, \\ University of Primorska, Cankarjeva 5, Koper, Slovenia \\ ${ }^{2}$ Department of Marketing, Faculty of Economics, University of Ljubljana, \\ Kardeljeva ploščad 17, Ljubljana, Slovenia \\ E-mails: ${ }^{1}$ mitja.ruzzier@fm-kp.si (corresponding author); ${ }^{2}$ maja.konecnik@ef.uni-lj.si
}

Received 27 December 2011; accepted 30 October 2012

\begin{abstract}
Export marketing and international business literature support the view that firm size-a reflection of number of employees, and sales-is positively related to export intensity and is a distinguishing factor between internationalized and non-internationalized firms. According to the resource-based view heterogeneous resource profiles that enable firms to achieve competitive advantage in international markets may be also such differentiating factors. On the other hand, as a result of the process of globalization and the increasing number of born global firms, firm age at entry into foreign markets is becoming negatively related to internationalization. Our findings just partly confirm the trends above. Using a regression model on the selected sample of 247 Slovenian small and medium enterprises, we have confirmed the hypotheses that internationalized companies are significantly larger (in terms of sales) and have more specialized resources (human, organizational, and financial resources) than non-internationalized companies. Organizational and human resources and the number of employees were positively and significantly related, while the age of companies at the start of their international activities was negatively related, to the extent of companies' internationalization. Different implications and conclusions for researchers and entrepreneurs are derived.
\end{abstract}

Keywords: internationalization, SMEs, firm size, firm age at entry, firm-level resources, exporting.

JEL Classification: L 25, L26.

\section{Introduction}

Internationalization is a phenomenon that has been researched intensively over the last few decades from a variety of viewpoints, ranging from organization theory to marketing, strategic management, international management, and small business research (e.g. Reuber, Fischer 1997; Manolova et al. 2010; Hoang 1998; Autio et al. 2000; Čater, Pučko 2010; Gomezelj Omezel, Antončič 2008). Thus, issues such as international decision-making and management, the development of international activities, and factors 
favoring or disfavoring internationalization have all been studied for large and small businesses separately (Ruzzier et al. 2006a). As it is necessary to choose between the two research settings (big versus small firms), the focus of this study is on small and medium enterprises (SMEs).

The social and economical importance of SMEs is obvious from the fact that they represent 99 percent of all enterprises in the European Union (EU or EU-27) and offer around 94 million jobs, which makes about two thirds of total employment in private sector in the EU. They are the primary engine of growth, particularly in terms of employment (Storey 1994; Hoffman et al. 1997). For Slovenia, a former socialistic republic, but now an open economy, integrated in the EU, the small business sector is extremely important. With the recent economic crises, where many large companies went bankrupted and with weak domestic purchasing power, its role is even increasing, especially in the context of entrance and operations on foreign markets.

Various variables have been used to explain and analyze the process of SMEs' internationalization. Past research in internationalization of SMEs has specially emphasized the role of firms demographic characteristics and the entrepreneur-related elements that impact export performance and export behavior, such as: attitudes, commitment, perceptions, orientations and international experience of managers, but researchers (Calof 1994; Miesenbock 1988) found that among the variables that characterize a firm, none has received as much research attention in the export literature as a firm's size. Recently, with the increasing globalization of economic activities, also firm's age in relation with international market entry is becoming an important differentiating factor (McDougall, Oviatt 1996, 2000). Furthermore, firm size and age provide simple criteria for segmenting firms into groups showing a similar export behavior and possibly similar problems that public support programs should deal with in a focused way. Thus, many researchers have included firm size and specific age as independent variables in their empirical studies.

The objective of this research is to test whether firm size, firm age at start of international activities, or availability of specific firm resources have positive or negative effects on small firm internationalization. At the same time we verify whether the selected variables represent distinguishing factors between internationalized and non-internationalized SMEs. The main contribution of the study is therefore to test the established relationships in previous research in a new context of a small, transition economy with short entrepreneurship tradition. Data were collected at an import time of countries' transition to a market economy, end of 2003, early before it became part of EU and it opened its country borders. We tested the proposed hypotheses using a regression model on the selected sample of 247 Slovenian small and medium enterprises.

\section{Theoretical background}

\subsection{The organization}

An individual firm can be seen as the combination of accumulated tangible and intangible resource stocks that are unique to the firm. These stocks, in turn, can be described as internal attributes of the firm, including assets, capabilities, processes, routines, and 
knowledge, which are tied semi-permanently to the firm and controlled by it (Barney 1991; Roth 1995; Wernerfelt 1997). Therefore, the firm can also be seen as an entity for knowledge accumulation and a bundle of heterogeneous resources (Penrose 1959). It is the experienced-based knowledge developed within the firm that determines its capability to exploit and combine its stock of heterogeneous resources for the production of specific services. Such knowledge gives each firm its unique character and a source of sustained competitive advantage (Das, Teng 2000; Penrose 1959; Trevino, Grosse 2002).

Resource-based view (RBV) logic identifies the kinds of resources and capabilities that require specific investment in order for their full economic value to be realized. When the realization of entrepreneurial depends on the use of socially complex or tacit resources and capabilities, it is more likely that a form of hierarchical governance (i.e., a firm) will be preferred over less hierarchical governance (i.e., the market). These ideas suggest that conditions requiring the efficient coordination and integration of knowledge are those in which entrepreneurial firms are likely to arise in the economy (Andersson 2000).

Penrose's and Nelson and Winter's definitions of a firm provide a contrast to traditional price theory, supporting a dynamic Schumpeterian understanding of competition. They sought to achieve a sensible balance between static and dynamic efficiency, where a firm tries to find a balance between exploiting already existing resources and (organizational) learning of new routines and capabilities (Ahokangas 1998; Knudsen 1995). We see that a possible methodological problem can arise, however, because decisions are actually made by people and not by impersonal entities such as firms. What a firm can do is to structure the activities of the different people who participate in the decision-making process. As the main decision-maker in SMEs is the entrepreneur, their decisions, characteristics and actions have the largest and most direct impact, therefore the firm is essentially a structure designed to harmonize decision-making efforts (Casson 1999).

\subsection{Firm size}

The administrative structure (Penrose 1959) and size of the firm (Casson 1999) reflect the founder's (leader's) vision, personal characteristics, organizational capabilities, and leadership qualities, as well as the pattern of volatility in the industry. Several researchers (Bonaccorsi 1992; Calof 1994; Miesenbock 1988) have found that among the variables that characterize a firm, none has received as much research attention in the export literature as firm size. Casson (1999) argued there are no fundamental differences between firms of different sizes, yet most studies (e.g., Man et al. 2002; Ruzzier et al. 2006b), especially in the context of a firm's internationalization (Coviello, Martin 1999; Erramilli, D’Souza 1993; Westhead et al. 2002) support the proposition that great differences exist between large corporations and SMEs (for a summary of findings on the relationship between a firm's size and export behavior, see Bonaccorsi 1992). 
A firm's size is also one of the most analyzed variables in exporting because many small firms perceive their lack of size as a handicap in exporting. The variable of firm size that has been used most frequently is number of employees, followed by sales volume. Man, Lau and Chan (2002) assert that small firms are not scaled-down versions of larger firms. Smaller firms differ from larger firms in their managerial style, independence, ownership, and scale/scope of operations (Coviello, Martin 1999). They have different organizational structures, responses to the environment and ways in which they compete with other firms (Man et al. 2002). Compared to their larger competitors, SMEs seem to have to overcome greater obstacles; however, by utilizing their specific advantages and discovering niche markets, they may compensate for their disadvantages (Buckley 1993; Pleitner et al. 1998). The strengths identified by researchers that are common to SMEs compared to larger companies include the following: high quality standards and individualized product/service offerings while enjoying a flexible cost structure, flexibility through the concentration of decision-making authority and short information structure, spontaneous ability to adapt to changing market environments and customer needs, and ability to avoid overpowering ideology and bureaucracy through personalized communication (Pleitner et al. 1998; Dass 2010).

Empirical findings have been mixed (Dass 2010), but on the whole they tend to show that larger companies have size-related advantages that enable them to more effectively engage in international operations (Aaby, Slater 1989; Miesenbock 1988). Firm size might allow an organization access to resources denied to smaller firms and thereby help organizations take risks, withstand setbacks, and initiate changes. Increased size provides more market power to an organization to deal with its stakeholders in technical as well as institutional environment (Dass 2010). In fact, Bloodgood, Sapienza, and Almeida (1996) found a positive relationship between firm size (number of employees) and the extent of internationalization. Further, in their study of 279 Wisconsin firms, Mehran and Moini (1999) reported that larger firms were more likely to be involved in exporting than their smaller counterparts. Similarly, Gemunden (1991) found that up to a certain minimum size the probability of exporting grows with increasing size, but beyond this limit there is only a weak association between size and exporting. While most studies concluded a positive relationship, others had mixed or negative results. An example is Gomez-Mejia's (1988) study of 388 Florida firms, which found no significant influence of company size and age on export performance. Bonaccorsi (1992) supported her findings on export behavior; however, when the dependent variable was export intensity, the results failed to support a positive relationship to firm size. The importance of firm size in the process of internationalization has also been confirmed in more recent studies. In their study of Bulgarian SMEs, Manolova et al (2010) found that firm size was positively and significantly associated with internationalization and varies by industry.

In spite of such efforts, there has been little consensus among researchers on the impact of this variable on international business operations. This is due to the fact that different size criteria, concepts, and methodologies are in use (Aaby, Slater 1989; Hoang 1998; Miesenbock 1988). Firm size has been proposed not only as a factor influencing 
internationalization, but also as a distinguishing factor between internationalized and non-internationalized firms. Therefore, we expect that internationalized firms will be larger (in terms of employees and sales) than non-internationalized firms and that firm size is positively and significantly related to higher degrees of internationalization. We thus posit the following hypotheses:

H1: Internationalized firms are significantly larger (have more employees and sales) than non-internationalized firms.

H2: Larger firms (in terms of employees and sales) will be statistically significant more internationalized.

\subsection{Firm-level resources}

More resources do not always mean better resources and better performance. While traditional international business and the international marketing literature equate larger size with greater resources, market power, and monopolistic advantage, which allow firms to overcome the sunk costs of internationalization (Caves 1982), the resource based view of the firm also suggests that heterogeneous resource profiles offer differential bases for achieving competitive advantage in international markets (Westhead et al. 2001). Heterogeneity among firms in owning and controlling key resources is according to the resources-based view also a fundamental driver for creating and maintaining a long-term sustainable competitive advantage (Barney 1991; Wernerfelt 1984) that supports their increasing involvement in international markets. To build and maintain them, firms must hold or have access to heterogeneous and idiosyncratic resources for opportunities identification and exploitation that current and potential rivals cannot easily duplicate (Amit, Schoemaker 1993; Barney 1991).

Erramilli and D'Souza (1993) identified two important interrelated characteristics of small firms: 1) resource constraints and 2) resource commitments under conditions of environmental uncertainty. Limited resources (especially capital resources) were identified as an important factor that distinguishes the strategic behavior of small firms from that of larger firms, while environmental uncertainty forces these firms to approach new investments cautiously and to minimize resource commitment (Erramilli, D'Souza 1993). In the context of internationalization, the resource scarcity of SMEs may have an impact on their ability to enter foreign markets and can also limit a smaller firm's ability to reach more advanced stages of internationalization (Westhead et al. 2001). The firm's growing international involvement requires more specialized and higher quality resource types as well as higher quantities of certain types (human, financial, and organizational) that can be owned or just controlled. Knowledge (and ability to learn) represented one on main resources for company early internationalization (Casillas et al. 2014; De Clercq et al. 2012) The evolution of export commitment might be limited by resource constraints; small firms can be expected to be handicapped in sustaining high levels of international involvement (Bonaccorsi 1992).

Resources in general can be considered stocks of available tangible or intangible factors that are owned or controlled by the firm and converted into products or services by using 
a variety of other resources and bonding mechanisms. Different resource classifications have been proposed (Grant 1991). Andrews (1971) defines organizational resources as the structure, processes, and systems in organisations which permit flows of information and training and which motivate organizational members. In a small company, organizational resources include employees' expertise, systems and policies, management systems, financial structures, planning and control systems, and the culture and employee skills of the firm. Presumably, management systems, routines, and employee skills are essential for reaching customers or providing superior levels of service. Efficient small firms are more capable of providing quality customer service, while those that develop human resources in the form of skilled employees are better able to respond to customer and market needs. Allocation of resource plays also a pivotal role in determining firm performance. The results of the study within Taiwanese firms suggest that firms would likely benefit by shifting their focus of resource allocation from R\&D to marketing (Chen, Hsu 2010).

Companies possessing more financial resources are able to pursue a broader range of activities as well as more ambitious projects (Cooper et al. 1994). Financial resources can be invested in capital-intensive projects that may enable firms to secure existing markets as well as enter new markets. In the study of T. Čater and B. Čater (2009) has been confirmed that firm's cost advantage is positively affected by financial resources and customer capital, while a differentiation advantage is positively affected by financial resource. In addition, both forms of competitive advantage positively influence a company's performance. Further, the financial barrier to exporting may be removed if a principal founder can secure external sources of finance based on their experience (and/ or the experience of the team of partners) (Westhead et al. 2001). Therefore, we expect that internationalized firms will have more competitive resource base that will secure them competitive advantage on international markets (in terms of organizational, human and financial resources) and firms with such resource structure will have higher degrees of internationalization. We thus posit the following hypotheses:

H3: Internationalized firms will have more competitive firm-level resource base (financial, human and organizational resources) than non-internationalized firms.

H4: Firms with more competitive firm-level resource base (financial, human and organizational resources) will be statistically significant more internationalized.

\subsection{Firm age}

Another important differentiating characteristic of firms is their age. There is a consensus in the empirical literature on the link between age, size, and (proportional) growth (Storey 1994); for any given size, the proportional growth rate of firms tends to decline with age. At the same time, older firms have a greater probability of survival than younger ones. Such patterns are consistent, for example, with models of firm selection where market entrants take time to learn about their relative efficiency. A selection process takes place and operates with greater intensity during the earlier part of the life cycle of firms. Consequently, young firms are marked by greater volatility of growth patterns than older firms. Young firms that are efficient during the initial selection pro- 
cess survive to maturity and settle down to relatively stable employment levels (OECD 2000).

The firm's age and time in the context of international entry are becoming important determinants of analysis in SME internationalization and international entrepreneurship. The abundant internationalization literature of the last 15 years reveals a focus in attention in international business studies on the issue of time, particularly the temporal dimension of international expansion (Zucchella et al. 2007). Time has been traditionally marginalized in international business studies (Ancona et al. 2001), but now new research fields are emerging which place time at their core, identifying it as a strategic dimension of SME internationalization (Ruzzier 2005). Certain studies that builds on the argument of specificity of the time of internationalization, in terms of internationalization correlates try even to separate international start-ups from small business internationalization, but such arguments are somewhat arbitrary at best (Antončič, Hisrich 2000). Secondly, the time dimension has different meanings, which can be specified in the following dimensions: the early start of international activities (called precocity), the speed of international growth (rapidity), or the pace occurring in international activities over time (Zucchella et al. 2007). In analyzing the drivers of the early start of internationalization, Zucchella et al. (2007) found that the role of the entrepreneur's previous experience, especially international experience (frequently nurtured in both internationally oriented family firms and multinational/foreign firms), was significant. A strategic move like the time of starting international activities may be influenced also by entrepreneurial alertness (Zahra et al. 2001). Because focalization is a reflection of entrepreneurial orientation and strategic decisions, the positive association between precocity and niche positioning of the business enforces the relevance of entrepreneurship.

The delay after start-up in obtaining foreign sales can also be considered a measure of international behavior (Reuber, Fischer 1997), even if recently researchers (e.g. Chetty et al. 2014) have proposed more complex conceptualizations to capture also other aspects of timing related to the speed of internationalization. Autio, Sapienza, and Almeida (2000) show that the age at which a firm internationalizes has an effect on entrepreneurial firm growth. Results from a sample on international new ventures in China demonstrate that the earliness of internationalization positively contributes to the firm performance in terms of sales growth, but not on innovation and profitability (Zhou, Wu 2014). According to learning and knowledge theory, firms that internationalize after they are domestically established must overcome a domestic orientation, international domestic political ties, and domestic decision-making inertia in order to enter foreign markets (McDougall, Oviatt 2000). Firms that internationalize earlier must have fewer of these barriers to overcome; thus, the earlier in its existence that an innovative firm internationalizes, the faster it is likely to grow, both overall and in foreign markets. Young firms without established routines that inhibit their learning opportunities in foreign environments may be able to grow more quickly than their counterparts who wait longer to internationalize (Autio et al. 2000). Older firms on the other hand have to overcome such as established processes, routines, and organizational norms that prohibited the translation of entrepreneurial behaviors into positive performance outcomes. 
This suggests that older firms particularly struggle with overcoming age-related contextual factors despite adopting an approach to strategy making that is otherwise conducive to achieving positive organizational growth (Anderson, Eshima 2011) on domestic or international markets.

In their literature review of the organizational determinants of exporting, Leonidou et al. (1998) identified two diametrically opposed views of the effect of business experience on export behavior. We have already described the group of companies that internationalizes upon or very soon after their inception. The other group of companies is more likely to export after gaining extensive experience in handling business operations in saturated home environments.

Age of firms and time after inception from their involvement in the process of internationalization is connected also with the establishment of inter-firm networks. Manolova et al. (2010) found that firm age negatively moderates the effect of inter-firm networks: the earlier the new venture engages in inter-firm collaboration, the higher the degree of its internationalization. This highlights the importance of speed in establishing contacts with other domestic firms. This supports also Gassmann's and Keupp's (2007) finding that rapid internationalization is positively associated with a specialized position in an international value chain. On the other hand, firms that do not internationalize early are likely to identify as domestic, cultivate networks that support their activities in the domestic market, and develop organizational practices that forego risky international expansion efforts (Autio et al. 2000).

Researchers who investigated firm age as a discriminating factor between internationalized and non-internationalized firms found inconsistent results. In Reuber and Fischer's (1997) study, age was not positively (and significantly) related to the degree of internationalization, but it demonstrated a negative relationship. Similarly, Ursic and Czinkota (1989) concluded that younger firms are more active in exporting than older ones. These results can be explained by the phenomenon of the increasing number of 'born global' firms internationalized from their inception, as well as the increasing globalization of businesses and environments. Therefore, we expect that companies that internationalize earlier from inception will have to overcome fewer routines, demonstrating their ability to grow faster and will be also more internationalized. We formalized our expectations in the following hypothesis:

H5: Firms that internationalize earlier from inception will be also more internationalized compared to those that internationalize later in their life cycle.

\section{Research methodology}

The methodology used in this research to test the hypotheses is discussed in terms of data collection, sample characteristics, measurement instruments, and data analysis.

\subsection{Data collection}

To test the hypotheses and determine the nature of the relationships, data were collected using a mail survey of Slovenian firms. The questionnaire was addressed to the top 
executive of each selected firm with anonymity guaranteed. Firms in the sample were selected from the most recent IPIS database, which includes all businesses in Slovenia. Dormant firms and firms with few employees were excluded from the population, leaving only SMEs with 10 to 250 employees. Response rates for mail surveys in Slovenia vary from $10 \%$ to $25 \%$; due to the length of the questionnaire in this study, a more conservative response rate of $10 \%$ to $15 \%$ was expected. To avoid additional costs of follow-up mailings and to ensure an adequate number of responses, the questionnaire was mailed to a random sample of 1,006 companies with international sales and 988 companies without foreign sales (altogether to 1,994 companies, covering all kinds of industry). The companies were randomly selected from a population of 4,050 companies with 10 to 250 employees and annual revenues of less than SIT 4 billion.

\subsection{Sample characteristics}

The postal survey resulted in 86 responses from non-internationalized companies and 161 responses from internationalized companies, which means a $13.5 \%$ overall response rate. After analyzing the extent and pattern of missing data, the whole sample of 247 usable responses was compensated for by using the combined method of imputation. Non-response bias for the whole sample of respondents was assessed based on the notion that 'later respondents' would be more like non-respondents (Armstrong, Overton 1977); the analysis showed that the non-response bias in this study is minimal.

The average firm in the sample had 20-49 employees, had SIT 100 million (about USD 483,000 ) to SIT 500 million (about USD 2.41 million) in sales, was 17.5 years old, operated in the manufacturing industry, and was located in the central geographical area of the country (the Slovenian capital of Ljubljana and its surroundings). This reflected the database population in terms of firm size, industry, and geographical location.

To compare the distribution of the sample to the database, a $t$-test for independent samples was used. It was found that the distribution of the sample differs slightly from the population. A significant difference was found for firm size in terms of full-time employees ( $t=-3.43,4290 \mathrm{df}$, sig. 0.00), annual sales $(t=-5.67,4289 \mathrm{df}$, sig. 0.00$)$ and industry $(t=2.06,4243 \mathrm{df}$, sig. 0.04$)$. These differences are mainly due to the lower number of responses received from smaller firms (10-19 employees) and the higher rate of participation of large firms (150-250 employees) and manufacturing firms. Hence, the sample is somewhat biased towards larger firms.

The sample represented all industries from the population. These included primary sector industries, manufacturing industries, construction, trade, and services. The sample also differed slightly from the population in terms of industry $(\mathrm{t}=2.06,4243 \mathrm{df}$, sig. 0.04), where manufacturing industries were better represented than construction and trade.

\subsection{Measurement instrument and data analysis}

Firm demographic characteristics in terms of firm size were analyzed across different measures. The number of full-time employees was analyzed first (they were classified in six groups ranging from 10 to 250 employees), followed by total sales in 2002 . To 
measure the competitiveness and availability of firm-level resources we have followed previous research (Greene et al. 1997), and divided them into three resource types; organizational, human, and financial. Organizational and human resources include systems, policies, culture, and the knowledge of organization members (other than the founders) as well as routines and structures. Following this definition, procedures, firm routines, and capabilities were measured using a five-item scale covering the following items: customer service capabilities, operating efficiencies, cost structure, employees with international experience, and multilingual staff. Financial resources were measured by a three-item scale: access to debt financing, access to equity financing, and domestic profitability. To obtain the variable of firm age at international entry, respondents were asked to check appropriate boxes for the age of the company at the time they began internationalization.

Following other researchers (Brush et al. 2002; Reuber, Fisher 1997), we tried to capture the multidimensionality of internationalization across the category of internationalization scale. Internationalization scale was measured by three items: percent of international sales, percent of products/services sold abroad, and percent of time employees dedicated to international activities.

The data were analyzed using univariate and multivariate statistical methods. Scales were tested for reliability. The relationships were tested using linear (stepwise) regression analyses. All analyses were performed using the SPSS statistical package (version 18). Constructed measures of internationalization scale, as well as financial, human and organizational resources, were created as an average of items included in the measure. Correlation matrix and descriptive statistics for all variables used in the study are presented in Appendixes 1 and 2.

\section{Results and discussions}

Firm characteristics of internationalized and non-internationalized companies were controlled in terms of firm size (number of employees and sales) and availability or quality of specific human, organizational, and financial resources. For internationalized companies, a regression analysis has been run to determine the influence of firm age at entry, firm size and availability of specific firm-level resource types on companies' internationalization.

The testing of demographic differences revealed some interesting findings. Firm size in terms of sales was found to be a significantly differentiating factor between internationalized and non-internationalized firms (sig. 0.004) but not in terms of full time employees (while internationalized companies had more employees, the difference was not significant; sig. $=0.522$ ). Internationalized companies scored significantly higher than non-internationalized companies in terms of all types of human, organizational, and financial resources (for a detailed comparison of resource bundles and their differences see Ruzzier et al. 2006b). Results of the comparisons are shown in Table 1. Therefore, Hypothesis 1 is just partly confirmed, while Hypothesis 3 is fully confirmed. 
Table 1. Comparison of firm characteristics between internationalized and non-internationalized firms

\begin{tabular}{|c|c|c|c|c|c|c|}
\hline \multirow{2}{*}{\multicolumn{2}{|c|}{ Variable }} & \multicolumn{2}{|c|}{$\begin{array}{l}\text { NON-INT } \\
(\mathrm{N}=86)\end{array}$} & \multicolumn{2}{|c|}{$\begin{array}{c}\text { INT } \\
(\mathrm{N}=161)\end{array}$} & \multirow{2}{*}{$\begin{array}{l}\text { Univariate } \\
\text { F-tests }\end{array}$} \\
\hline & & Mean & St. dev. & Mean & St. dev. & \\
\hline \multirow{2}{*}{ Size } & Full-time employees (FTE) & 2.03 & 1.32 & 2.14 & 1.20 & .522 \\
\hline & Sales (SA) & 4.32 & 1.49 & 4.85 & 1.23 & $.004 * *$ \\
\hline \multicolumn{7}{|c|}{ Organizational \& human resources } \\
\hline \multicolumn{2}{|c|}{ Operating efficiencies (OE) } & 3.20 & 1.57 & 3.86 & 1.00 & $16.231 * * *$ \\
\hline \multicolumn{2}{|c|}{ Cost structure (CS) } & 2.92 & 1.54 & 3.53 & 1.06 & $13.433 * * *$ \\
\hline \multicolumn{2}{|c|}{ Customer service capabilities (CSC) } & 2.84 & 1.70 & 3.58 & 1.20 & $15.629 * * *$ \\
\hline \multicolumn{2}{|c|}{$\begin{array}{l}\text { Employees with international } \\
\text { experience (EIE) }\end{array}$} & 2.22 & 1.62 & 3.50 & 1.14 & $51.869 * * *$ \\
\hline \multicolumn{2}{|c|}{ Multilingual staff (MS) } & 2.75 & 1.60 & 3.92 & 1.06 & $46.946^{* * *}$ \\
\hline \multicolumn{7}{|c|}{ Financial resources } \\
\hline \multicolumn{2}{|c|}{ Access to debt financing (DEF) } & 2.32 & 1.62 & 2.83 & 1.46 & $6.068 *$ \\
\hline \multicolumn{2}{|c|}{ Access to equity capital (EC) } & 2.19 & 1.15 & 2.86 & 1.40 & $12.180 * * *$ \\
\hline \multicolumn{2}{|c|}{ High domestic profits (DOP) } & 2.32 & 1.55 & 2.71 & 1.30 & $4.378^{*}$ \\
\hline
\end{tabular}

Notes: *significant at $\mathrm{p}<0.05 ; * *$ significant at $\mathrm{p}<0.01 ; * * *$ significant at $\mathrm{p}<0.001 ;$ NON-INT - noninternationalized firms, INT - internationalized firms.

For internationalized companies a linear (stepwise) regression analysis has been performed to determine the influence of firm age at entry into foreign markets, size and resources on companies' internationalization. To reduce the scales into factors, a separate factor analysis was performed using Principal component analysis method and Oblimin with Kaiser normalization rotation. Results of the factor and regression analysis are shown in Tables 2-4. Explorative factor analysis combined measured into 4 factors that were mostly in line with theory, except for human and organizational resources that were merged into one factor. Due to strong integration and dependency of organizational resources from human factors it was an acceptable solution and we continued our analyses with keeping the four proposed factors. The final model of the stepwise regression analysis included the following variables that exceeded the significance level: human and organizational resources, employees, and time of entry. All scales passed the reliability test and exceeded the level of 0.8 (human and organizational resources Cronbach $\alpha=0.839$; financial resources Cronbach $\alpha=0.823$; internationalization scale Cronbach $\alpha=0.830$ ). The variables of financial resources, and sales were excluded from the final regression model because not reaching the significance level. R Square in the first step of the stepwise regression model was 0.041 and in the second step 0.067 . The final model was stable (Multiple $\mathrm{R}=0.302$; $\mathrm{R}$ Square $=0.091$; Adjusted R Square $=$ 0.074) and statistically significant (sig. 0.002). 
Table 2. Factor analysis results with item factor loadings

\begin{tabular}{|c|c|c|c|c|}
\hline & \multicolumn{4}{|c|}{ Component } \\
\hline & $\begin{array}{c}\text { Hum \& } \\
\text { org. r. }\end{array}$ & $\begin{array}{l}\text { Fin. } \\
\text { res. }\end{array}$ & Size & $\begin{array}{c}\text { Age at } \\
\text { entry }\end{array}$ \\
\hline Operating efficiencies (OE) & .854 & & & \\
\hline Multilingual staff (MS) & .837 & & & \\
\hline Employees with international experience (EIE) & .809 & & & \\
\hline Cost structure (CS) & .750 & & & \\
\hline Customer service capabilities (CSC) & .660 & & & \\
\hline Access to equity capital (EC) & & .889 & & \\
\hline Access to debt financing (DEF) & & .851 & & \\
\hline High domestic profits (DOP) & & .816 & & \\
\hline Full-time employees (FTE) & & & .873 & \\
\hline Sales (SA) & & & .827 & \\
\hline Age at entry & & & & .950 \\
\hline
\end{tabular}

Legend: Extraction method: Principal component analysis. Rotation method: Oblimin with Kaiser normalization.

The most important predictors of internationalization scale from the selected variables (in the final model) were found to be human and organizational resources, which were positively and significantly related to internationalization (standardized coefficient $=$ 0.156 , sig. $<0.05$ ), followed by the time of entry, which was negatively related to internationalization (standardized coefficient $=-0.173$, sig. $<0.05$ ), and the number of employees with the positive relationship (standardized coefficient $=0.205$, sig. $<0.01$ ) . In other words, we can say that the extent of the internationalization of Slovenian SMEs (as percent of international sales, percent of products/services sold abroad, and percent of time employees dedicated to international activities) was positively influenced by the number of full-time employees, by the competitiveness of available human and organizational resources (including customer service capabilities, operating efficiencies, cost structure, and employees with international experience and multilingual staff) and negatively by the age of start from establishment of their international activities. The resulting linear regression model can be written as follows (model 3):

INT scale $=a+b 1 *$ hum\&org.res. $-b 2 *$ age at entry $+b 3$ N. of employees. (1) With the inclusion of the parameters (model 3, unstandardized coefficients):

INT scale $=1.27+0.149 *$ hum\&org.res. $-0.102 *$ age at entry + $0.379 \mathrm{~N}$. of employees. 
Table 3. Analyses of variance (ANOVA) for the regression analyses

\begin{tabular}{lccccc}
\hline & Sum of squares & df & Mean square & F & Sig. \\
\hline Regression & 19.001 & 3 & 6.334 & 5.158 & $.002^{* *}$ \\
\hline Residual & 189.120 & 154 & 1.228 & & \\
\hline Total & 208.121 & 157 & & & \\
\hline
\end{tabular}

Note: ${ }^{* *}$ significant at $\mathrm{p}<0.01$.

Table 4. Coefficients for the regression analyses

\begin{tabular}{|c|c|c|c|c|c|}
\hline \multirow[t]{2}{*}{ Variable/Model } & \multicolumn{2}{|c|}{$\begin{array}{l}\text { Unstandardized } \\
\text { coefficients }\end{array}$} & \multirow{2}{*}{$\begin{array}{c}\text { Standardized } \\
\text { coefficients }\end{array}$} & \multirow[t]{2}{*}{$\mathrm{t}$} & \multirow[t]{2}{*}{ Sig. } \\
\hline & $\mathrm{B}$ & Std. error & & & \\
\hline \multicolumn{6}{|l|}{ Model 1} \\
\hline (Constant) & 1.331 & .397 & & 3.350 & $.001 * *$ \\
\hline Human \& organiz. res. & .374 & .145 & .202 & 2.574 & $.011^{*}$ \\
\hline \multicolumn{6}{|l|}{ Model 2} \\
\hline (Constant) & 1.532 & .405 & & 3.786 & $.000 * * *$ \\
\hline Human \& organiz. res. & .394 & .144 & .213 & 2.738 & $.007 * *$ \\
\hline Time of entry & -.096 & .046 & -.163 & -2.096 & $.038^{*}$ \\
\hline \multicolumn{6}{|l|}{ Model 3} \\
\hline (Constant) & 1.270 & .421 & & 3.015 & $.003 * *$ \\
\hline Human \& organiz. res. & .149 & .074 & .156 & 2.021 & $.045^{*}$ \\
\hline Time of entry & -.102 & .045 & -.173 & -2.239 & $.027 *$ \\
\hline Employees & 0.379 & 0.143 & 0.205 & 2.654 & $0.009 * *$ \\
\hline
\end{tabular}

Notes: significant at $\mathrm{p}<0.05 ;{ }^{*}$ significant at $\mathrm{p}<0.01 ; * * *$ significant at $\mathrm{p}<0.001$.

The regression model was controlled also for industry. Companies had to specify the industry group they belong to based on the standardized classification of companies valid in Slovenia. Accordingly they were further grouped just into two categories; production ( 85 companies) and service companies (76 firms). The regression model for the subsample of production companies was statistically significant (sig. 0.003; R Square $=$ 0.134; Adjusted R Square $=0.12$ ), while only organizational and human resources had a positive and significant influence on internationalization scale (standardized coefficient $=0.366$, sig. $<0.01$ ). When service companies were analyzed, the model and none of the predictors were significant, even if they showed the expected directions of relationships. Such findings could be partially attributed to the small size of subsamples. On the other hand they show that in the production companies' organizational and human resources (including operating efficiencies, multilingual staff, employees with international experience, cost structure and customer service capabilities) are even more important for internationalization that in service companies. 
The above findings lead us to the full confirmation of Hypothesis 5 (related to age at entry) when the entire sample of companies was considered. Actually when the time perspective was considered as the age of companies from the inception to the start of their international activities, the relationship has been found negative and significant. This means that the younger the companies start with their international activities, the more they are internationalized (on average). This is consistent also with the previous theoretical findings (McDougall, Oviatt 1996; McDougall et al. 1994) and other trends, such as the increasing globalization of economic environments and the increasing number of internationally experienced entrepreneurs who are able to recognize the required amount, quality and type of critical resources for international activities.

When analyzing the relationships between firm size, and firm's specific resources availability, the results have been mixed. Hypothesis 2 (firm size) and Hypothesis 4 (firm-level resources) have received just partial support since financial resources and the amount of sales have not received support. Accordingly, we have tried to find some explanations in the literature. Bonaccorsi (1992) in her widely cited article regarding the relationships among firm size, age, and internationalization of SMEs, identified some theoretical inconsistencies and misleading conclusions. She argues that the relationship between firm resources and export behavior and performance is not direct but mediated by strategy, at the function level (export strategy) and at the business level (competitive strategy). The amount and quality of firm resources needed for international involvement depends on the export strategy adopted and implemented (Bonaccorsi 1992). A similar argument may be relevant for our findings, though we cannot yet prove it. We feel that the mediated influence of strategy in the relationship of size and internationalization performance is especially relevant for companies of a transitional economy like Slovenia. When the economy started to open their border, especially in the years after Slovenia's entrance into the European Union and after losing its foreign single Yugoslav market, companies adopted very different strategies, which we believe mediated the relationship of their size, internationalization performance and behavior. Companies that oriented toward ex-Yugoslav markets (e.g. Croatia and Serbia, which are still very important trading partners), based their strategies primarily on certain type of human resources (personal networks of the main entrepreneurs and employees, cultural knowledge, multilingual staff, previous international experience), while companies that oriented their exports toward the more competitive markets of western EU countries had to adopt strategies based on specific organizational resources (customer service capabilities, operating efficiencies) to strengthen their competitive position. Within the five biggest Slovenian export countries in 2011, we find four west EU countries and Croatia, which we may link to the positive and significant relationship between the amount of human and organizational resources and internationalization scale.

The variables of firm size in terms of full-time employees and firm sales should also be discussed. Full-time employees have not been found to be a differentiating factor between internationalized and non-internationalized companies (even if internationalized companies have been bigger on average that non-internationalized ones), while the number of employees significantly influenced the internationalization scale (of already 
internationalized companies). Therefore, we believe that the importance of the number of employees increases with international involvement, which means that involvement in international activities is a combination of quantitative and qualitative involvement. An opposing situation occurred when firm sales were analyzed. Internationalized companies were significantly bigger than non-internationalized companies in terms of firm sales, while firm sales did not significantly influence the level of internationalization scale.

The discussion related to firm size and the influence on internationalization scale could be extended further to large companies. Probably the results related to resources, number of employees and sales would be similar also for them, up to certain level, but the relevance of the measures of internationalization scale would start to be questioned. Larger companies with their increase of international involvement actually increase more in complexity (e.g. different and more capital/knowledge intensive modes of operation) and in integration of international activities (sourcing, human resources, R\&D) than in the internationalization scale. Therefore for larger companies different measures should be adopted to capture the multidimensionality of internationalization (e.g. TNI transnational index) and the relationship to the size of the companies.

\section{Conclusions}

The objective of the study was to examine the importance of demographic characteristics (firm age and size) and resources availability in the internationalization of Slovenian small and medium enterprises. This is in a new context of a small transition economy with short entrepreneurship tradition. In our study, the idea that firm demographic characteristics and specialized resources availability were distinguishing factors between internationalized and non-internationalized firms received mixed support. Analyses performed on the selected sample of Slovenian SMEs partly confirmed our expectations that firm size are distinguishing factors in internationalization. With regard to firm size, internationalized companies were expected to be significantly bigger than non-internationalized companies in terms of full-time employees, sales, and selected types of resources. This was true in terms of sales and resources (organizational, human, and financial), but not in terms of full-time employees (an expected difference, but not significant).

The next conclusion we can derive from our findings is that quality and availability of human and organizational resources is important in all phases of the internationalization process and increases with the extent of the companies' international involvement (differentiating factor between internationalized and non-internationalized companies; significant influence on the internationalization scale), while the size of companies (number of full-time employees) becomes important in later stages of international involvement. We also found that such resources are even more important for internationalized production companies that for service companies.

When we consider the age of companies when entering foreign markets in relation to the internationalization of SMEs, we can conclude that, in order to reach higher in- 
ternationalization performance levels, entrepreneurs and their companies should begin internationalization at or soon after inception. This is probably because the companies that start with their internationalization activities later in their life cycle, they have to overcome also greater internal barriers, that arise from their established routines adapted to domestic operations. In this perspective we can advice owners/managers of SMEs to start with their international involvement as soon as possible from inception or even design their companies' organizational structure and resources in the way they will be prepared for international growth.

This study has some limitations. One potential problem is the research methodology. The proposition that size significantly influences export intensity, or represents a distinguishing factor between internationalized and non-internationalized companies, assumes that the causal direction is from company resources availability and quality, and size to actual export behavior. The reverse, however, might also be true: export involvement might lead to an increase in size and improvement of the quality of certain resources that would not be possible by selling in the domestic market. This possibility has not been acknowledged in the literature. Furthermore, the search for causal explanations should always control for the time dimension. Company size, resources availability and quality, and export intensity may be the result of different processes with different time paths, so that a statistical correlation at any point in time should not be assumed to be a proof of a causal linkage.

The generalization of results may be also limited if we consider the development of countries under investigation (e.g. in terms of GDP/capita). The starting level of resources and the supporting environment in developed countries are much different than in developing countries. This may significantly influence the behavior of companies approaching international markets. A potential limitation could be also the time of data collection, which dates back in 2003, but all conclusions and implications are valid still today. Due to the economic crisis affecting most European countries and their domestic markets, the results even increase in relevance, because companies are forced to seek their opportunities and demand on foreign and more distant markets.

The findings from this study imply that the increased quality and availability of certain firm-level resources may have bigger impact for production companies that for service companies in relation to their international involvement. This is specifically relevant for policy makers when crafting and investing in internationalization support programs which have bigger impact when they are targeted and adapted just to certain type of companies, in this case production companies.

Implications for further research are as follows. First, expanded measures of resources, such as human and social resources, should be utilized. To verify our interpretations of the results, a longitudinal study with a follow-up survey would provide more insights into demographic characteristics and resource development. Second, further research should control differences for internationalization in terms of industry, since different industries result in different added value per employee and number of employees (size criteria). In more competitive industries, with higher technology, probably more com- 
panies will be internationalized. Third, our study investigated only small and mediumsized companies located in Slovenia. Our findings are therefore generalizable to this population of SMEs. Additional research using a sample derived from an international population would both enhance the generalizability of the findings and add a muchdesired comparative element to the study.

\section{References}

Aaby, N. E.; Slater, S. F. 1989. Management influence on export performance: a review of the empirical literature 1978-1988, International Marketing Review 6(4): 7-22.

http://dx.doi.org/10.1108/EUM0000000001516

Ahokangas, P. 1998. Internationalization and resources: an analysis of processes in Nordic SMEs. Doctoral dissertation. Vaasa: Universitas Wasaensis.

Amit, R.; Schoemaker, P. J. H. 1993. Strategic asset and organizational rent, Strategic Management Journal 14(1): 33-46. http://dx.doi.org/10.1002/smj.4250140105

Ancona, D., et al. 2001. Time: a new research lens, The Academy of Management Review 26(4): 645-663.

Anderson, B. S.; Eshima, Y. 2011. The influence of firm age and intangible resources on the relationship between entrepreneurial orientation and firm growth among Japanese SMEs, Journal of Business Venturing 28(3): 413-429. http://dx.doi.org/10.1016/j.jbusvent.2011.10.001

Andersson, S. 2000. The internationalization of the firm from an entrepreneurial perspective, International Studies of Management \& Organization 30(1): 63-93.

Andrews, K. L. 1971. The concept of corporate strategy. Homewood, IL: Irwin.

Antončič, B.; Hisrich, R. D. 2000. An integrative conceptual model, in L. P. Dana (Eds.). Global marketing co-operation and networks. New York: International Business Press, 17-35.

Armstrong, J. S.; Overton, T. S. 1977. Estimating nonresponse bias in mail surveys, Journal of Marketing Research 14(3): 396-402. http://dx.doi.org/10.2307/3150783

Autio, E.; Sapienza, H. J.; Almeida, J. G. 2000. Effects of age at entry, knowledge intensity, and imitability on international growth, Academy of Management Journal 43(5): 909-924.

http://dx.doi.org/10.2307/1556419

Barney, J. 1991. Firm resources and sustained competitive advantage, Journal of Management 17(1): 99-120. http://dx.doi.org/10.1177/014920639101700108

Bloodgood, J. M.; Sapienza, H. J.; Almeida, J. G. 1996. The internationalization of new highpotential U.S. ventures: antecedents and outcomes, Entrepreneurship Theory and Practise 20(4): 61-76.

Bonaccorsi, A. 1992. On the relationship between firm size and export intensity, Journal of International Business Studies 23(4): 605-636. http://dx.doi.org/10.1057/palgrave.jibs. 8490280

Brush, C.; Edelman L.; Manolova, T. 2002. The impact of resources on small firm internationalization, Journal of Small Business Strategy 13(1): 1-17.

Buckley, P. J. 1993. Foreign direct investment by small-and medium-sized enterprises: the theoretical background, in P. J. Buckley, P. N. Ghauri (Eds.). The internationalization of the firm: a reader. London: Academic Press, 91-106.

Calof, J. 1994. The relationship between firm size and export behavior revisited, Journal of International Business Studies 25(2): 367-387. http://dx.doi.org/10.1057/palgrave.jibs.8490205 
Casson, M. 1999. Entrepreneurship and the theory of the firm, in Z. J. Acks, B. Carlsson, C. Karlsson (Eds.). Entrepreneurship, small and medium-sized enterprises and the macroeconomy. Cambridge: Cambridge University Press, 45-78.

Chetty, S.; Johanson, M.; Martin, M. O. 2014. Speed of internationalization: conceptualization, measurement and validation, Journal of World Business 49(4): 633-650.

Čater, T.; Čater, B. 2009. (In)tangible resource as antecedents of a company's competitive advantage and performance, Journal of East European Management Studies 14(2): 186-209.

Čater, T.; Pučko, D. 2010. Factors of effective strategy implementation: empirical evidence from Slovenian business practice, Journal of East European Management Studies 15(3): 207-236.

Casillas, J. C.; Barbero, J. L.; Sapienza, J. H. 2014. Knowledge acquisition, learning, and the initial pace of internationalization, International Business Review 24(1): 102-114.

http://dx.doi.org/10.1016/j.ibusrev.2014.06.005

Caves, R. E. 1982. Multinational enterprise and economic analysis. Cambridge, UK: Cambridge University Press.

Chen, H.; Hsu, C.-W. 2010. Internationalization, resource allocation and firm performance, Industrial Marketing Management 39: 1103-1110. http://dx.doi.org/10.1016/j.indmarman.2009.10.001

Cooper, A. C.; Gimeno-Gascon, F. J.; Woo, C. Y. 1994. Initial human and financial capital predictors of new venture performance, Journal of Business Venturing 9(5): 371-395.

http://dx.doi.org/10.1016/0883-9026(94)90013-2

Coviello, N. E.; Martin, K. 1999. Internationalization of service SMEs: an integrated perspective from the engineering consulting sector, Journal of International Marketing 7(4): 42-66.

Das, T. K.; Teng, B.-S. 2000. A resource-based theory of strategic alliances, Journal of Management 26(1): 31-61.

Dass, P. 2010. Relationship of firm size, initial diversification, and internationalization with strategic change, Journal of Business Research 48: 135-146.

http://dx.doi.org/10.1016/S0148-2963(98)00097-6

De Clercq, D.; Sapienza, H. J.; Yavuz, R. I.; Zhu, L. 2012. Learning and knowledge in early internationalization research: past accomplishments and future directions, Journal of Business Venturing 27(1): 143-165.

Erramilli, K. M.; D’Souza, D. 1993. Venturing into foreign markets: the case of small service firm, Entrepreneurship Theory and Practise 17(4): 29-41.

Gassmann, O.; Keupp, M. M. 2007. The competitive advantage of early and rapidly internationalizing SMEs in the biotechnology industry: a knowledge-based view, Journal of World Business 42: 350-366. http://dx.doi.org/10.1016/j.jwb.2007.04.006

Gemunden, H.-G.1991. Success factors of export marketing: a meta-analytic critique of the empirical studies, in S. J. Paliwoda (Ed.). New perspectives on international marketing. London: Routledge.

Gomezelj Omerzel, D.; Antončič, B. 2008. Critical entrepreneur knowledge dimensions for the SME performance, Industrial Management \& Data System 108(9): 1182-1199.

http://dx.doi.org/10.1108/02635570810914883

Gomez-Mejia, L. 1998. The role of human resources strategy on export performance: a longitudinal study, Strategic Management Journal 9(5): 493-505.

http://dx.doi.org/10.1002/smj.4250090508

Grant, R. M. 1991. Resource-based theory of competitive advantage: implications for strategy formulation, California Management Review 33(3): 114-135. http://dx.doi.org/10.2307/41166664 Greene, P. G.; Brush, C. G.; Brown, T. E. 1997. Resources in small firms: an exploratory study, Journal of Small Business Strategy 8(2): 29-40. 
Hoang, P. 1998. A causal study of relationships between firm characteristics, international marketing strategies, and export performance, Management International Review 38(1): 73-93.

Hoffman, K.; Parejo, M.; Bessant, J.; Perren, L. 1997. Innovation amongst small and mediumsized enterprises, Technovation 18: 39-55 http://dx.doi.org/10.1016/S0166-4972(97)00102-8

Knudsen, C. 1995. Theories of the firm, strategic management, and leadership, in C. A. Montgomery (Ed.). Resource-based and evolutionary theories of the firm: toward a synthesis. Boston: Kluwer Academic Publishers, 179-217. http://dx.doi.org/10.1007/978-1-4615-2201-0_8

Leonidou, L.; Katsikeas, C.; Piercy, N. 1998. Identifying managerial influences on exporting: past research and future directions, Journal of International Marketing 6(2): 74-103.

Man, T. W. Y.; Lau, T.; Chan, K. F. 2002. The competitiveness of small and medium enterprises: a conceptualisation with focus on entrepreneurial competencies, Journal of Business Venturing 17(2): 123-142. http://dx.doi.org/10.1016/S0883-9026(00)00058-6

Manolova, T. S.; Manev, I. M.; Gyoshev, B. S. 2010. In good company: the role of personal and inter-firm networks for new-venture internationalization in a transition economy, Journal of World Business 45: 257-265. http://dx.doi.org/10.1016/j.jwb.2009.09.004

McDougall, P. P.; Oviatt, B. M. 1996. New venture internationalization, strategic change, and performance: a follow-up study, Journal of Business Venturing 11(1): 23-40.

http://dx.doi.org/10.1016/0883-9026(95)00081-X

McDougall, P. P.; Oviatt, B. M. 2000. International entrepreneurship: the intersection of two research paths, Academy of Management Journal 43(5): 902-906. http://dx.doi.org/10.2307/1556418

McDougall, P. P.; Shane, S.; Oviatt, B. M. 1994. Explaining the formation of international new ventures: the limits of theories from international business research, Journal of Business Venturing 9(6): 469-487. http://dx.doi.org/10.1016/0883-9026(94)90017-5

Mehran, J.; Moini, A. H. 1999. Firms' export behavior, American Business Review 17(1): 86-93. Miesenbock, K. J. 1988. Small business and exporting: a literature review, International Small Business Journal 6(2): 42-61. http://dx.doi.org/10.1177/026624268800600204

OECD Small and Medium Enterprise Outlook. 2000. Paris: OECD, Head of Publications Service. Penrose, E. 1959. The theory of the growth of the firm. Oxford: Oxford University Press.

Pleitner, J.; Brunner, J.; Habersaat, M. 1998. Fors and extent of success factors: the case of Switzerland, in A. Haahti, G. Hall, R. Donckels (Eds.). The internationalization of SMEs: the Interstratos project. London: Routledge, 27-55.

Reuber, R. A.; Fischer, E. 1997. The influence of the management team's international experience on the internationalization behaviours of SMEs, Journal of International Business Studies 28(4): 807-826. http://dx.doi.org/10.1057/palgrave.jibs.8490120

Roth, K. 1995. Managing international interdependence: CEO characteristics in a resource based framework, Academy of Management Journal 38(1): 200-231. http://dx.doi.org/10.2307/256733

Ruzzier, M. 2005. International entrepreneurship: small and medium companies' internationalization model. Kranj: Arak.

Ruzzier, M.; Hisrich, R. D.; Antončič, B. 2006a. SME internationalization research: past, present, and future, Journal of Small Business and Enterprise Development 13(4): 476-497.

http://dx.doi.org/10.1108/14626000610705705

Ruzzier, M.; Antončič, B.; Konečnik, M. 2006b. The resource-based approach to the internationalisation of SMEs: differences in resource bundles between internationalised and non-internationalised companies, Zagreb International Review of Economics and Business 9(2): 95-116.

Storey, D. G. 1994. Understanding the small business sector. London: Routledge. 
Trevino, L. J.; Grosse, R. 2002. An analysis of the firm specific resources and foreign direct investment in the United States, International Business Review 11(4): 431-452.

http://dx.doi.org/10.1016/S0969-5931(02)00018-5

Ursic, M. L.; Czinkota, M. R. 1989. The relationship between managerial characteristics and exporting behavior, Developments in Marketing Science 12: 208-10.

Wernerfelt, B. 1997. A resource-based view of the firm, in N. J. Foss (Eds.). Resources, firms and strategies: a reader in the resource-based perspective. Oxford: Oxford University Press, 117-130.

Wernerfelt, B. 1984. A resource-based view of the firm, Strategic Management Journal 5(2): 171-180. http://dx.doi.org/10.1002/smj.4250050207

Westhead, P.; Wright, M.; Ucbasaran, D. 2001. The internationalization of new and small firms: a resource based view, Journal of Business Venturing 16(4): 333-358.

http://dx.doi.org/10.1016/S0883-9026(99)00063-4

Westhead, P.; Wright, M.; Ucbasaran, D. 2002. International market selection strategies by 'micro' and 'small' firms, The International Journal of Management Science 30(1): 51-68.

Zhou, L.; Wu, A. 2014. Earliness of internationalization and performance outcomes: exploring the moderating effects of venture age and international commitment, Journal of World Business 49(1): 132-142.

Zahra, S.; Hayton, J.; Marcel, J.; O’Neill, H. 2001. Fostering: entrepreneurship during international expansion: managing key challenges, European Management Journal 19(4): 359-369. http://dx.doi.org/10.1016/S0263-2373(01)00037-8

Zucchella, A.; Palamara, G.; Denicolai, S. 2007. The drivers of the early internationalization of the firm, Journal of World Business 42: 268-280. http://dx.doi.org/10.1016/j.jwb.2007.04.008 


\section{APPENDIX 1}

Table 5. Correlation matrix for all variables used in the study

\begin{tabular}{|c|c|c|c|c|c|c|c|c|c|c|c|c|c|c|c|}
\hline & & FTE & SA & MS & EIE & $\mathrm{CSC}$ & $\mathrm{OE}$ & CS & DEF & EC & DOP & AGE_E & $\%$ EX_P & $\%$ TIME & $\%$ EX_S \\
\hline \multirow{3}{*}{ FTE } & Pearson C. & 1 & $.455^{* *}$ & -.021 & .069 & .040 & .052 & .104 & .040 & -.115 & -.061 & .063 & .104 & .120 & $.186^{*}$ \\
\hline & Sig. (2-t) & & .000 & .796 & .384 & .617 & .517 & .189 & .613 & .147 & .445 & .432 & .190 & .132 & .019 \\
\hline & $\mathrm{N}$ & 160 & 158 & 160 & 160 & 160 & 160 & 160 & 160 & 160 & 160 & 160 & 160 & 160 & 160 \\
\hline \multirow{3}{*}{ SA } & Pearson C. & $.455^{* *}$ & 1 & .118 & $.156^{*}$ & .087 & .146 & .096 & .148 & .132 & $.159^{*}$ & -.127 & .106 & .068 & .129 \\
\hline & Sig. $(2-t)$ & .000 & & .138 & .049 & .273 & .065 & .227 & .062 & .096 & .045 & .109 & .183 & .396 & .106 \\
\hline & $\mathrm{N}$ & 158 & 159 & 159 & 159 & 159 & 159 & 159 & 159 & 159 & 159 & 159 & 159 & 159 & 159 \\
\hline \multirow{3}{*}{ MS } & Pearson C. & -.021 & .118 & 1 & $.713^{* *}$ & $.454^{* *}$ & $.598^{* *}$ & $.467^{* *}$ & $.244^{* *}$ & .119 & $.230^{* *}$ & .008 & .056 & $.165^{*}$ & .074 \\
\hline & Sig. (2-t) & .796 & .138 & & .000 & .000 & .000 & .000 & .002 & .131 & .003 & .915 & .481 & .037 & .353 \\
\hline & $\mathrm{N}$ & 160 & 159 & 161 & 161 & 161 & 161 & 161 & 161 & 161 & 161 & 161 & 161 & 161 & 161 \\
\hline \multirow{3}{*}{ EIE } & Pearson C. & .069 & $.156^{*}$ & $.713^{* *}$ & 1 & $.444^{* *}$ & $.566^{* *}$ & $.415^{* *}$ & $.248^{* *}$ & .137 & .152 & .026 & $.203^{* *}$ & $.349^{* *}$ & $.268^{* *}$ \\
\hline & Sig. $(2-t)$ & .384 & .049 & .000 & & .000 & .000 & .000 & .002 & .084 & .054 & .742 & .010 & .000 & .001 \\
\hline & $\mathrm{N}$ & 160 & 159 & 161 & 161 & 161 & 161 & 161 & 161 & 161 & 161 & 161 & 161 & 161 & 161 \\
\hline \multirow{3}{*}{$\mathrm{CSC}$} & Pearson C. & .040 & .087 & $.454^{* *}$ & $.444^{* *}$ & 1 & $.444^{* *}$ & $.401^{* *}$ & $.308^{* *}$ & $.270^{* *}$ & $.219^{* *}$ & .110 & -.016 & .039 & .033 \\
\hline & Sig. (2-t) & .617 & .273 & .000 & .000 & & .000 & .000 & .000 & .001 & .005 & .164 & .842 & .627 & .677 \\
\hline & $\mathrm{N}$ & 160 & 159 & 161 & 161 & 161 & 161 & 161 & 161 & 161 & 161 & 161 & 161 & 161 & 161 \\
\hline \multirow{3}{*}{$\mathrm{OE}$} & Pearson C. & .052 & .146 & $.598^{* *}$ & $.566^{* *}$ & $.444^{* *}$ & 1 & $.682^{* *}$ & $.219^{* *}$ & .055 & $.257^{* *}$ & -.004 & $.183^{*}$ & $.283^{* *}$ & $.247^{* *}$ \\
\hline & Sig. $(2-t)$ & .517 & .065 & .000 & .000 & .000 & & .000 & .005 & .490 & .001 & .959 & .020 & .000 & .002 \\
\hline & $\mathrm{N}$ & 160 & 159 & 161 & 161 & 161 & 161 & 161 & 161 & 161 & 161 & 161 & 161 & 161 & 161 \\
\hline \multirow{3}{*}{ CS } & Pearson C. & .104 & .096 & $.467^{* * *}$ & $.415^{* *}$ & $.401^{* *}$ & $.682^{* *}$ & 1 & $.312^{* *}$ & .092 & $.293^{* *}$ & .108 & .127 & .132 & $.172^{*}$ \\
\hline & Sig. $(2-t)$ & .189 & .227 & .000 & .000 & .000 & .000 & & .000 & .244 & .000 & .172 & .107 & .096 & .029 \\
\hline & $\mathrm{N}$ & 160 & 159 & 161 & 161 & 161 & 161 & 161 & 161 & 161 & 161 & 161 & 161 & 161 & 161 \\
\hline \multirow{3}{*}{ DEF } & Pearson C. & .040 & .148 & $.244^{* *}$ & $.248^{* *}$ & $.308^{* *}$ & $.219^{* *}$ & $.312^{* *}$ & 1 & $.665^{* *}$ & $.567^{* *}$ & .111 & -.023 & .027 & .051 \\
\hline & Sig. $(2-t)$ & .613 & .062 & .002 & .002 & .000 & .005 & .000 & & .000 & .000 & .161 & .775 & .737 & .517 \\
\hline & $\mathrm{N}$ & 160 & 159 & 161 & 161 & 161 & 161 & 161 & 161 & 161 & 161 & 161 & 161 & 161 & 161 \\
\hline \multirow{3}{*}{ EC } & Pearson C. & -.115 & .132 & .119 & .137 & $.270^{* *}$ & .055 & .092 & $.665^{* * *}$ & 1 & $.591^{* *}$ & .011 & -.050 & -.008 & -.003 \\
\hline & Sig. (2-t) & .147 & .096 & .131 & .084 & .001 & .490 & .244 & .000 & & .000 & .895 & .533 & .924 & .966 \\
\hline & $\mathrm{N}$ & 160 & 159 & 161 & 161 & 161 & 161 & 161 & 161 & 161 & 161 & 161 & 161 & 161 & 161 \\
\hline \multirow{3}{*}{ DOP } & Pearson C. & -.061 & $.159^{*}$ & $.230^{* *}$ & .152 & $.219^{* *}$ & $.257^{* *}$ & $.293^{* *}$ & $.567^{* * *}$ & $.591^{* *}$ & 1 & .100 & -.081 & -.061 & -.082 \\
\hline & Sig. (2-t) & .445 & .045 & .003 & .054 & .005 & .001 & .000 & .000 & .000 & & .206 & .307 & .439 & .299 \\
\hline & $\mathrm{N}$ & 160 & 159 & 161 & 161 & 161 & 161 & 161 & 161 & 161 & 161 & 161 & 161 & 161 & 161 \\
\hline \multirow{3}{*}{ AGE_E } & Pearson C. & .063 & -.127 & .008 & .026 & .110 & -.004 & .108 & .111 & .011 & .100 & 1 & $-.188^{*}$ & -.140 & -.145 \\
\hline & Sig. $(2-t)$ & .432 & .109 & .915 & .742 & .164 & .959 & .172 & .161 & .895 & .206 & & .017 & .077 & .067 \\
\hline & $\mathrm{N}$ & 160 & 159 & 161 & 161 & 161 & 161 & 161 & 161 & 161 & 161 & 161 & 161 & 161 & 161 \\
\hline \multirow{3}{*}{$\%$ EX_P } & Pearson C. & .104 & .106 & .056 & $.203^{* *}$ & -.016 & $.183^{*}$ & .127 & -.023 & -.050 & -.081 & $-.188^{*}$ & 1 & $.746^{* *}$ & $.832^{* *}$ \\
\hline & Sig. (2-t) & .190 & .183 & .481 & .010 & .842 & .020 & .107 & .775 & .533 & .307 & .017 & & .000 & .000 \\
\hline & $\mathrm{N}$ & 160 & 159 & 161 & 161 & 161 & 161 & 161 & 161 & 161 & 161 & 161 & 161 & 161 & 161 \\
\hline \multirow{3}{*}{ \%TIME } & Pearson C. & .120 & .068 & $.165^{*}$ & $.349^{* *}$ & .039 & $.283^{* *}$ & .132 & .027 & -.008 & -.061 & -.140 & $.746^{* *}$ & 1 & $.658^{* *}$ \\
\hline & Sig. (2-t) & .132 & .396 & .037 & .000 & .627 & .000 & .096 & .737 & .924 & .439 & .077 & .000 & & .000 \\
\hline & $\mathrm{N}$ & 160 & 159 & 161 & 161 & 161 & 161 & 161 & 161 & 161 & 161 & 161 & 161 & 161 & 161 \\
\hline \multirow{3}{*}{$\%$ EX_S } & Pearson C. & $.186^{*}$ & .129 & .074 & $.268^{* *}$ & .033 & $.247^{* *}$ & $.172^{*}$ & .051 & -.003 & -.082 & -.145 & $.832^{* *}$ & $.658^{* *}$ & 1 \\
\hline & Sig. $(2-t)$ & .019 & .106 & .353 & .001 & .677 & .002 & .029 & .517 & .966 & .299 & .067 & .000 & .000 & \\
\hline & $\mathrm{N}$ & 160 & 159 & 161 & 161 & 161 & 161 & 161 & 161 & 161 & 161 & 161 & 161 & 161 & 161 \\
\hline
\end{tabular}

Notes: *Correlation is significant at the 0.05 level (2-tailed). ${ }^{*}$ Correlation is significant at the 0.01 level (2-tailed).

Full-time employees (FTE), Sales (SA), Operating efficiencies (OE), Cost structure (CS), Customer service capabilities (CSC), Employees with international experience (EIE), Multilingual staff (MS), Access to debt financing (DEF), Access to equity capital (EC), High domestic profits (DOP), percent of international sales (\%EX_S), percent of products/services sold abroad (\%EX_P), and percent of time employees dedicated to international activities (\%TIME), age at entry (AGE_E). 


\section{APPENDIX 2}

Table 6. Descriptive statistics for all variables used in the study

\begin{tabular}{lccccc}
\hline & $\mathrm{N}$ & Mean & Std. error & $\begin{array}{c}\text { Std. } \\
\text { deviation }\end{array}$ & Variance \\
\hline Full-time employees (FTE) & 160 & 2.14 & .095 & 1.202 & 1.445 \\
\hline Sales (SA) & 159 & 4.85 & .097 & 1.228 & 1.509 \\
\hline Multilingual staff (MS) & 161 & 3.93 & .084 & 1.062 & 1.129 \\
\hline Employees with international experience (EIE) & 161 & 3.50 & .090 & 1.146 & 1.313 \\
\hline Customer service capabilities (CSC) & 161 & 3.58 & .095 & 1.201 & 1.442 \\
\hline Operating efficiencies (OE) & 161 & 3.87 & .079 & 1.001 & 1.003 \\
\hline Cost structure (CS) & 161 & 3.54 & .084 & 1.069 & 1.142 \\
\hline Access to debt financing (DEF), & 161 & 2.87 & .110 & 1.400 & 1.961 \\
\hline Access to equity capital (EC) & 161 & 2.83 & .116 & 1.470 & 2.161 \\
\hline High domestic profits (DOP) & 161 & 2.72 & .103 & 1.309 & 1.713 \\
\hline Age at entry (AGE_E) & 161 & 2.66 & .155 & 1.966 & 3.864 \\
\hline Valid N (listwise) & 158 & & & & \\
\hline
\end{tabular}

Mitja RUZZIER is Professor of Entrepreneurship and chair of the Entrepreneurship Department at the Faculty of Management, University of Primorska. He teaches different courses about Entrepreneurship and International Business at the undergraduate and postgraduate level. His research interest lies in the area of Internationalization, International marketing, Branding, Innovation, SMEs and Entrepreneurship. He has many practical experiences and he works part time as consultant for many companies. His papers were published in different academic journals such as the Entrepreneurship and Regional Development, Transformations in Business and Economics, Managing Global Transition, Canadian Journal of Administrative Science, Journal of Small Business and Enterprise Development and others. He has published also different books about Entrepreneurship.

Maja KONECNIK RUZZIER is the Associate Professor of Marketing at the Faculty of Economics, University of Ljubljana (FELU). Professor Konecnik Ruzzier has authored or co-authored more than 30 papers on branding, marketing, tourism, destination and SME, which have appeared in such journals as Journal of Business Research, Annals of Tourism Research, Journal of Brand Management, Journal of Travel Research, Canadian Journal of Administrative Sciences, Baltic Journal of Management. Her articles are highly cited. She has served on some editorial boards and acted as a referee for more than 20 scientific journals. Dr Konecnik Ruzzier is a course director for courses related to marketing principles in general, tourism marketing and branding at the FELU. She also acts as a Visiting Professor at some foreign universities. 